\title{
Effect of Plant Growth Regulator on Growth, Yield and Catechin Content of Tea (Camellia sinensis (L.) O.Kuntze)
}

\author{
Intan Ratna Dewi Anjarsari ${ }^{a}{ }^{,}$, Jajang Sauman Hamdani ${ }^{\text {a }}$, Cucu Suherman ${ }^{\text {a }}$, Tati Nurmala ${ }^{\text {a }}$, \\ Erdiansyah Rezamela ${ }^{b}$, Heri Syahrian Khomaeni ${ }^{b}$, Vitria Puspitasari Rahadi ${ }^{b}$ \\ ${ }^{a}$ Department of Agrotechnology, Padjadjaran University, Sumedang, 45363, Indonesia \\ ${ }^{b}$ Indonesian Research Institute for Tea and Cinchona, Gambung, Ciwidey, West Java, Indonesia \\ Corresponding author: *intan.ratna@unpad.ac.id
}

\begin{abstract}
Catechins are one of the secondary metabolites contained in tea leaves. Cultivation practices such as pruning affect the shoot production and quality of tea yield. The use of plant growth regulators is a new breakthrough in tea plant engineering. This research aims to determine the interaction effect of type, height of pruning, and concentration of Benzil Amino Purine (BAP) and Gibberellin (GA) concentrations on tea plants' growth and catechin content after pruning. The experiment was conducted at Tea and Cinchona Research Centre Gambung in June 2018 until October 2018, with a split-plot design consisted of three factors as followed: main factor (a) type of pruning (clean and lung pruning); subfactor (b) pruning height $(40 \mathrm{~cm}, 50 \mathrm{~cm}$, and $60 \mathrm{~cm})$; sub-sub factor (h) plant growth regulator (0 ppm, $60 \mathrm{ppm}$ BAP, $50 \mathrm{ppm}$ GA, $60 \mathrm{ppm}$ BAP $+50 \mathrm{ppm}$ GA). The result showed that $60 \mathrm{~cm}$ pruning and $60 \mathrm{ppm}$ BAP in the third month after pruning significantly affected the chlorophyll content index $(91,58 I$ cci). There was an interaction between the pruning height of $60 \mathrm{~cm}$ and $50 \mathrm{ppm}$ GA on fresh shoots weight per bush on the fourth plucking. Based on the response curve, at clean pruning, the optimum value at pruning height of $51.5 \mathrm{~cm}$ and $66,63 \mathrm{ppm}$ BAP contributes to the catechin content of $1.88 \%$ while at lung pruning, the minimum value pruning height of $50.73 \mathrm{~cm}$ and $7.238 \mathrm{ppm}$ with catechin content of $0.776 \%$.
\end{abstract}

Keywords - Benzil Amino Purine (BAP); catechins; gibberellin (GA); pruning.

\section{INTRODUCTION}

Tea is a superior commodity that has a significant role in Indonesia, contributing to the country's foreign exchange and absorbs much labor. As a world tea producer, Indonesia produced 140 thousand tons made tea per year and exported 49 thousand tons in 2018. The average tea production is produced from a number of farmers, the private sector, and State-Owned Enterprises. About $70 \%$ of the raw materials for tea are produced by many West Java tea farmers, while the remaining 30\% from farmers in Central Java, East Java, North Sumatra, and Bengkulu [1]. Global tea consumption is projected to increase by almost $3 \%$ annually over the coming decade [2]. Catechins are one derivative of polyphenols that have high antioxidant properties. Catechins play an important role in determining flavor and taste. In terms of health, the higher catechins are, the more beneficial for health.

The constituents of polyphenolic compounds, especially individual catechins, depend on altered with the change in cultivation altitude. According to Jiang et al. [3], the catechin content in tea leaves varies depending on the season; fresh leaves plucked in spring season produced the strongest theaflavins (the catechin component). The percentage of catechins to total polyphenol was increased with increasing altitude. The temperature is being increased due to climate change. Rising temperatures at lower altitudes will deteriorate tea quality because of climate warming [4]. Furthermore, in tea leaves, high contents of certain individual catechins lead to a high yield of theaflavin. Although processing technologies impact the quality of tea, according to Zhang et al., geographical location and other environmental factors significantly affect the quality of tea [5].

In addition to proper plucking, the yield of the tea plant can be increased through optimal maintenance, agronomic practices, including regular pruning, and application of plant growth regulators to initiate shoot growth after pruning. According to productivity and quality of tea in the field are affected with $35 \%$ cultivation techniques, $25 \%$ clones, 25 fields managerial, and $15 \%$ climate [6]. The results of Wakamatsu et al. showed that catechin content in green tea 
leaves varies according to cultivation conditions such as intensity of solar radiation, temperature, and precipitation. Thus, there is ambiguity about the best harvest time for obtaining optimal functional effects [7]. Firouzi and Azarian showed that timely pruning of tea bush has desirable effects on the quantity and quality of the final product, and tea bushes are pruned in three forms of light prune, medium prune, and collar prune [8].

Pruning carried out cyclically to provide vegetative growth stimuli, rectify bush architecture, and maintain the perfect frame height of the bushes for efficient plucking. Pruning attempts to break the apical dominance and promote lateral growth during the growing season [9]. The difference lies in many leaves and branches that must be left behind and the high level of pruning from the ground surface. A study conducted by Mohale et al. [10] showed that the pruned (top) and unpruned tea plants exhibited higher levels of metabolites than the basal and middle pruned. Pruning bush tea showed a significant effect on the accumulation of secondary metabolites and thus could enhance bush tea quality. Top pruning (apically pruned) resulted in improved metabolite accumulation than other treatments and can be recommended in bush tea cultivation.

Shoot growth is a process that is controlled by interactions between hormones, nutrients, and environmental factors [11]. Until recently, shoot growth after pruning occurred naturally without the addition of growth regulators (ZPT). Cytokinin, which triggers cell division, controls every aspect of plant growth and development, including meristem function, vascular development, stress responses, senescence, and no less important, maintaining the stem cell population in the SAM (shoot apical meristem) [12].

Some research results show satisfactory results in terms of the use of cytokinin and gibberellin. Benzyl Amino Purine (BAP) is a cytokinin that is often used because it is most effective for stimulating the formation of shoots, is more stable and resistant to oxidation, and is the cheapest among other cytokinin's. The use of 200 or $400 \mathrm{mg} . \mathrm{L}^{-1}$ 6-BA significantly increased spring tea yield by $28.9 \%$ or $13.3 \%$, respectively as compared with the control. 6-BA at the four concentrations promoted dwarfing and the formation of productive lateral branches and increased the spring yield, and 200 mg.L ${ }^{-1}$ 6-BA exerted the best comprehensive effect [13]. According to Anjarsari et al. [14], BAP application can improve plant growth and development. This indicated that the provision of growth regulators can be used to accelerate the growth of tea plants after being pruned. The results of Rosniawaty et al. [15] research that cytokinin derived from coconut water or BAP applied in tea plants after centering was only effective up to 3 months after application. At 1 and 3 months after application, $50 \%$ coconut water or BAP $60 \mathrm{ppm}$ increased the length of stem diameter, a number of leaves, shoot length, and number of shoots. Another growth regulators used are Giberelin (GA). GA is one of the phytohormones that regulate numerous important biological processes in plant development [16]. GA has been shown to regulate plant shade response positively [17], and GA also controls certain biological processes in response to stress [18].

The background of this study is that the use of growth regulators in plantations in immature plants and mature plants applied to pruned tea plants is a new breakthrough in plant cultivation engineering, especially tea as an annual plant, to increase growth and yield. This study aims to determine the interaction effect of type, height of pruning and BAP, and GA concentrations on tea plants' growth and catechin levels after pruning. An important point in this research is that pruning, and the application of growth regulators can affect the parameter studied. Application of BAP and GA to tea plants after pruning is expected to affect catechin content positively.

\section{MATERIALS AND METHOD}

\section{A. Materials and Plot Preparation}

The study was carried out at the Indonesian Research Institute for Tea and Chincona Gambung Ciwidey (1200 m above sea level) from July to October 2018 and the soil type of Andisol. The seven years old pruned tea plants of GMB7 clones are used as planting material. Benzil Amino Purine (BAP) and Gibberellin (GA) used as plant growth regulators. The materials used for catechin analysis are $\mathrm{CHCl} 3$ p.a, Ethyl acetate p.a, Solven Polyphenol (acetonitrile mixture: ethyl acetate: $\mathrm{H}_{3} \mathrm{PO}_{4} 85 \%=12: 2: 86$ ), and standard substances. The materials used for the molecular experiment were ethanol, isopropanol, phenol, chloroform, liquid nitrogen, CTAB buffer, PCR kit, primer, aquades, TE buffer, and milliQ. The experiment designed into split-plot consisting of three factors as followed: main factor (a) (two type of pruning consist of clean and lung pruning); sub-factor (b) pruning height consist three levels $(40 \mathrm{~cm}, 50 \mathrm{~cm}$ and $60 \mathrm{~cm}$ from ground level); sub-sub factor (plant growth regulator (PGR) consist four-level (0 ppm, 60 ppm BAP, 50 ppm GA, 60 ppm $\mathrm{BAP}+50$ ppm GA).

\section{B. Research Procedures}

The first treatment for tea plants is pruning. Production pruning that is generally done is clean pruning and pruning or lung pruning. After pruning, the tea plant is then initiated by shoot growth by providing growth regulators (BAP and GA). Tea shoot plucking is done after 6 times of tipping with plucking cycle once every 14 days done as much as 6 times plucking. Application of Benzil Amino Purine (BAP) and Gibberellin (GA) is carried out six times in the plucking period by spraying BAP and GA solution in the tea bush canopy.

\section{Growth and Yield Measurement}

Chlorophyll measurement of tea leaves was carried out on the mature leaves in the production plucking phase using SPAD type chlorophyll meter three times to obtain the index data of the ovary leaves' chlorophyll content cci units (chlorophyll content index). Fresh shoot weights produced from production $(\mathrm{g})$, are carried out after six plucking times with a 14-day plucking cycle. Wet shoot weights are weighed each time plucking. Dry shoot production weight $(\mathrm{g})$, carried out at the same time as in the case of observation of fresh shoot weights. Fresh shoot from the plucking medium is taken as much as $100 \mathrm{~g}$ and then dried in the oven for approximately 48 hours $\pm 80^{\circ} \mathrm{C}$ until the weight is constant, then weighed.

\section{Catechin Analysis}

Catechin analysis was carried out at the Bogor Agricultural Post-Research Center Research and Development 
Laboratory, and Catechin Analysis was accumulated every four times. The initial step in the catechin analysis is to dry the shoot samples of $100 \mathrm{~g}$ using an oven at $80^{\circ} \mathrm{C}$ for 10 hours. After that, puree the sample until it is completely smooth. Catechin analysis was performed using an HPLC tool. The method used according to the Official Method of Analysis of the Association of Official Analytical Chemists (AOAC) [19]. The stages are shown in Figure 1 below:

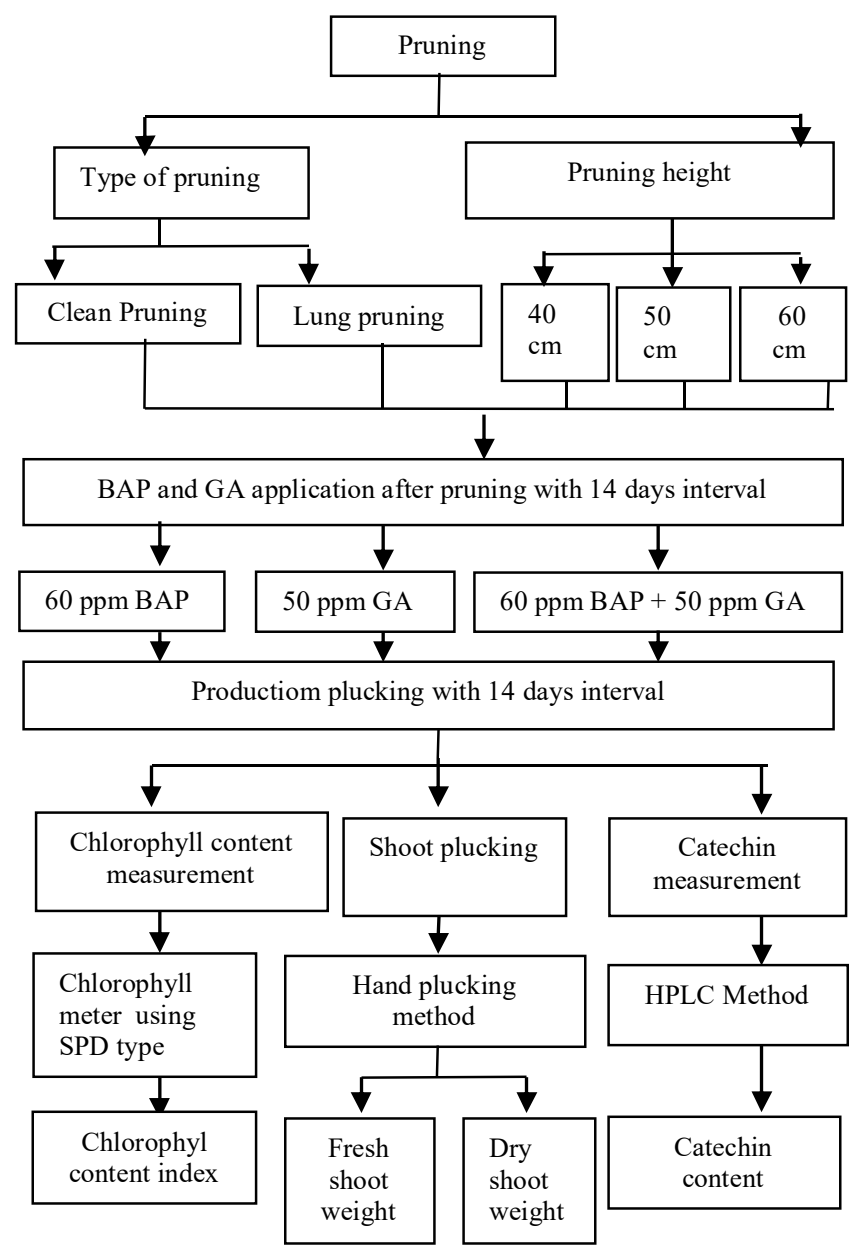

Fig. 1 Flowchart of research method

The initial stage in catechin analysis was to dry the shoot sample as much as $100 \mathrm{~g}$ using an oven at $80^{\circ} \mathrm{C}$ for 10 hours. After that, grind the sample until it is completely smooth. Catechin analysis was performed using HPLC tools. The first step is making a standard curve by making a standard series of $\mathrm{c}$. Measure the standard solution according to the HPLC requirements and create a calibration curve and determine the value of $b$ through zero. Dissolve the solvent and shake until homogeneous, then filter with $0.45 \mu \mathrm{l}$ milex HA into a special (closed) test tube. The next step is to do sample preparation by weighing $1 \mathrm{~g}$ of fine tea and put it in a $500 \mathrm{ml}$ Erlenmeyer flask. Put the distilled water to boil $\pm 200 \mathrm{ml}$ and boil for 5 minutes then cool (assisted with cooling). Put it in a $250 \mathrm{ml}$ volumetric flask, mark it with distilled water, and then shake it until it is homogeneous. The next step is to filter the solution into $100 \mathrm{ml}$ Erlenmeyer to obtain $\pm 100 \mathrm{ml}$ filtrate, then pipette $25 \mathrm{ml}$ of the solution obtained and put it into a $250 \mathrm{ml}$ separating funnel. Add $50 \mathrm{ml}$ of $\mathrm{CHCl}_{3}$ p.a to the solution in a $250 \mathrm{ml}$ separating funnel and then shake it for 2 minutes (do
3 times). The bottom layer of $\mathrm{CHCl}_{3}$ is accommodated into a $100 \mathrm{ml}$ beaker glass. The sample solution (top layer) was extracted with $3 \times 50 \mathrm{~mL}$ ethyl acetate p.a, ethyl acetate solution (top layer containing polyphenol) was collected into a boiling flask. Steam the ethyl acetate solution with a Roravapor tool until it is almost dry, dissolve it with solvent into a $50 \mathrm{ml}$ volumetric flask, mark it, and shake it until it is homogeneous. Filter the solution with Milex HA $0.45 \mu$, then inject it into the HPLC equipment.

\section{E. Data Analysis}

Parameter data is analyzed statistically with the $\mathrm{F}$ test (Fisher Exact Test) at 5\% level; if the difference between treatments appears, Duncan at level $5 \%$ test will be conducted. The flowchart of the research method is illustrated in Fig. 1.

\section{RESULTS AND DISCUSSION}

\section{A. Chlorophyll Content Index of Mature Leaves}

Chlorophyll concentrations undergo significant increases as the leaf develops, while polyphenol decreases as the leaf mature [20]. Permanent leaves are used as maintenance leaves to ensure productivity and survival. The upper layers of maintenance leave mainly supply photosynthates for shoot growth, whereas the lower layer supplies the branches, stems, and roots.

Table I shows the leaf chlorophyll content index in the third month. There was an interaction effect between pruning height and PGR concentration on the chlorophyll index of mature leaves. Pruning height of $60 \mathrm{~cm}$ combined with a BAP of $60 \mathrm{ppm}$ has a significant effect on the increase in chlorophyll content with a value of 91.58 cci. Application 50 ppm GA prevents its effect on $50 \mathrm{~cm}$ pruning height. The combination of $60 \mathrm{ppm}$ BAP and $50 \mathrm{ppm}$ GA did not have any effect at various clipping heights.

TABLE I

INTERACTION EFFECT OF PRUNING HEIGHT AND PGR CONCENTRATION ON THE AVERAGE CHLOROPHYLL CONTENT INDEX (CCI) OF 3-MONTH MATURE LEAVES

\begin{tabular}{rcccc}
\hline \multirow{2}{*}{$\begin{array}{l}\text { Pruning } \\
\text { height }\end{array}$} & \multicolumn{4}{c}{ PGR concentration } \\
\cline { 2 - 5 } & $\mathbf{0 ~ p p m}$ & $\begin{array}{l}\text { 60 ppm } \\
\text { BAP }\end{array}$ & $\begin{array}{c}\mathbf{5 0} \mathbf{~ p p m} \\
\text { GA }\end{array}$ & $\begin{array}{c}\text { 60 ppm } \\
\text { BAP + 50 } \\
\text { ppm GA }\end{array}$ \\
\hline $40 \mathrm{~cm}$ & $88.06 \mathrm{~b}$ & $86.97 \mathrm{a}$ & $86.32 \mathrm{a}$ & $84.14 \mathrm{a}$ \\
& $\mathrm{B}$ & $\mathrm{AB}$ & $\mathrm{AB}$ & $\mathrm{A}$ \\
$50 \mathrm{~cm}$ & $84.00 \mathrm{a}$ & $86.88 \mathrm{a}$ & $89.13 \mathrm{a}$ & $85.72 \mathrm{a}$ \\
& $\mathrm{A}$ & $\mathrm{A}$ & $\mathrm{B}$ & $\mathrm{A}$ \\
$60 \mathrm{~cm}$ & $87.75 \mathrm{ab}$ & $91.58 \mathrm{~b}$ & $88.25 \mathrm{a}$ & $87.25 \mathrm{a}$ \\
& $\mathrm{A}$ & $\mathrm{B}$ & $\mathrm{A}$ & $\mathrm{A}$ \\
\hline
\end{tabular}

Note: The average number marked with the same letter (uppercase horizontal and lowercase vertical) is not significantly different according to Duncan's test of $5 \%$.

According to Davies [21], cytokinin can play a role in leaf expansion which is caused by cell enlargement. The leaf area is adjusted to account for root growth, reflected by the cytokinin amount that reaches the shoot [22]. Cytokinin contributes to chloroplast development, where its application accumulates chlorophyll and increases the conversion rate of etioplastic to chloroplasts.

Chloroplasts provide energy for plants by producing sugar during photosynthesis. To adapt to various environmental and 
developmental conditions, plants have developed specific strategies to control chloroplast homeostasis in cells, including chloroplast degradation during leaf senescence and the transition of chloroplast into other types of plastids during the day-night cycle [23]. Chloroplast contains chlorophyll, is the place of photosynthesis, and is also involved in the biosynthesis of many important primary and secondary metabolites [24]. Cytokinin prolongs antioxidant-based protection in chloroplasts, extending their lifespan [25]. The chlorophyll content in tea increases gradually as the leaves mature and significantly improves photosynthesis [26].

\section{B. Fresh Shoot Weight}

Shoot wet weight is a production parameter that is generally analyzed in studies related to tea to determine treatment effects on tea yield. Table II shows an interaction effect between pruning height and PGR concentration on the fresh weight of the tea shoot. The treatment of $60 \mathrm{~cm}$ pruning height with 50 ppm GA showed a significant effect on wet production weight and does not significantly differ from 40 $\mathrm{cm}$ pruning height and $50 \mathrm{ppm}$ GA. This shows that the application of GA can increase tea shoot production per bush. Gibberellin intermediate is a precursor of GA that is not biologically active and is a product of biosynthesis in the active GA biosynthetic pathway. Efflux GA carriers, also known as transporters, can transport GA from the cytosol to apoplast (GA exporters). GA is transported through proteins across the plasma membrane from apoplast to cytosol (GA importer) [27].

TABLE II

INTERACTION EFFECT OF PRUNING HEIGHT AND PGR CONCENTRATION ON SHOOT FRESH WEIGHT PER BUSH $(\mathrm{g})$

\begin{tabular}{|c|c|c|c|c|}
\hline \multirow[b]{2}{*}{$\begin{array}{c}\text { Pruning } \\
\text { height }\end{array}$} & \multicolumn{4}{|c|}{ PGR concentration } \\
\hline & 0 ppm & $\begin{array}{c}60 \text { ppm } \\
\text { BAP }\end{array}$ & $\begin{array}{c}50 \text { ppm } \\
\text { GA }\end{array}$ & $\begin{array}{c}60 \text { ppm } \\
\text { BAP + 50 } \\
\text { ppm GA }\end{array}$ \\
\hline $40 \mathrm{~cm}$ & $\begin{array}{c}8.55 a \\
\text { A }\end{array}$ & $\begin{array}{c}12.24 b \\
B C\end{array}$ & $\begin{array}{c}15.22 b \\
C\end{array}$ & $\begin{array}{c}9.62 \mathrm{a} \\
\mathrm{AB}\end{array}$ \\
\hline $50 \mathrm{~cm}$ & $\begin{array}{c}13.15 b \\
B\end{array}$ & $\begin{array}{c}13.47 \mathrm{~b} \\
\mathrm{~B}\end{array}$ & $\begin{array}{c}13.79 b \\
B\end{array}$ & $\begin{array}{c}12.43 b \\
B\end{array}$ \\
\hline $60 \mathrm{~cm}$ & $\begin{array}{c}9.64 a b \\
\mathrm{AB}\end{array}$ & $\begin{array}{c}8.31 \mathrm{a} \\
\mathrm{A}\end{array}$ & $\begin{array}{c}16.10 b \\
C\end{array}$ & $\begin{array}{c}12.32 \mathrm{a} \\
\mathrm{B}\end{array}$ \\
\hline
\end{tabular}

Note: The average number marked with the same letter (uppercase horizontal and lowercase vertical) is not significantly different according to Duncan's test of $5 \%$

GA is applied to regulate the bud activity-dormancy transition in tea plants. Suppressing the growth of banjhi shoots indirectly stimulates pecco growth, increasing shoot wet weight [28]. According to Shu et al. [29], GA is one of the phytohormones that regulate biological processes crucial to plant development and has positively regulated plant shade and tea plant response [30]. Another research showed that the application of GA $100 \mathrm{mg}$. L-1 increased the rate of net photosynthesis (Pn), chlorophyll content, and chlorophyll fluorescence parameters of the 1 st and 6th leaves of Camellia oleifera [31].

Exogenous gibberellins begin the transport of photosynthesis from leaves to buds from the source sink relationship regulator. Photosynthates produced in maintained leaves have many uses inside the leaves and are also converted to sucrose in sinks. The process that allocates the amount of carbon is called photosynthate or carbon partitioning. After arriving at the sink, photosynthates are partitioned again to be used as an energy source for growth or for food reserves in the form of carbohydrates, proteins, and oils [32].

The type of shoots produced determines tea yield; the younger the shoots are picked, the higher the quality. Shoot growth and contents that determine tea quality are influenced by plant conditions, soil fertility, season, age after pruning, and altitude. Rough plucking yields a high production with low shoot quality, while fine plucking yields a low production with high shoot quality [33]. In general, tea plantations utilize a medium plucking method. Therefore, the plucking method directly determines shoot quality (percentage of young shoots). According to Mitrowihardjo [34], quality correlates significantly with taste. Approximately $50-60 \%$ of tea leaf quality is influenced by post-process appearance, which is greatly influenced by the weight of existing pecco.

\section{Dry Shoot Weight}

The result of the analysis (Table III) showed that there was no significant difference in shoot dry weight during production plucking, presumably due to water absorption and limited nutrients in the dry season.

TABLE III

INDEPENDENT EFFECTS OF PRUNING HEIGHT AND PGR CONCENTRATION OF ON AVERAGE SHOOT DRY WEIGHT $(\mathrm{g})$

\begin{tabular}{|c|c|c|c|c|c|}
\hline \multirow[b]{2}{*}{$\begin{array}{l}\text { Pru } \\
\text { ning } \\
\text { type }\end{array}$} & \multirow[b]{2}{*}{$\begin{array}{c}\text { Pru } \\
\text { ning } \\
\text { height }\end{array}$} & \multicolumn{4}{|c|}{ PGR concentration } \\
\hline & & O ppm & $\begin{array}{c}60 \text { ppm } \\
\text { BAP }\end{array}$ & $\begin{array}{c}50 \text { ppm } \\
\text { GA }\end{array}$ & $\begin{array}{c}60 \mathrm{ppm} \\
\text { BAP + } \\
50 \mathrm{ppm} \\
\text { GA }\end{array}$ \\
\hline Clean & $40 \mathrm{~cm}$ & $26.84 a$ & $23.00 \mathrm{a}$ & $25.33 \mathrm{a}$ & $26.37 \mathrm{a}$ \\
\hline \multirow[t]{2}{*}{ Pruning } & $50 \mathrm{~cm}$ & $26.65 a$ & $26.01 \mathrm{a}$ & $26.49 a$ & $25.35 a$ \\
\hline & $60 \mathrm{~cm}$ & $21.93 \mathrm{a}$ & $24.45 \mathrm{a}$ & $27.17 \mathrm{a}$ & $23.99 a$ \\
\hline lung & $40 \mathrm{~cm}$ & $25.02 \mathrm{a}$ & $25.61 \mathrm{a}$ & $24.21 \mathrm{a}$ & $24.21 \mathrm{a}$ \\
\hline \multirow[t]{2}{*}{ pruning } & $50 \mathrm{~cm}$ & $26.12 \mathrm{a}$ & $25.18 \mathrm{a}$ & $26.52 \mathrm{a}$ & $24.20 \mathrm{a}$ \\
\hline & $60 \mathrm{~cm}$ & $25.96 a$ & $26.76 \mathrm{a}$ & $24.18 \mathrm{a}$ & $26.98 \mathrm{a}$ \\
\hline
\end{tabular}

Limited water during low rainfall causes fertilizers to be insoluble and not absorbed by plant roots and decreases photosynthesis rates in maintenance leaves. Low soil moisture causes plants to lose more water than the amount absorbed by roots, which causes wilting leaves, closing stomata, and reduced carbohydrate production due to decreased photosynthesis. Carbohydrates are needed as energy to absorb nutrients so that a lack of water in plants results in reduced absorption of $\mathrm{CO}_{2}$, water, and nutrients [35].

During observation, factors that influenced the absence of interaction between pruning method and height are rainfall, temperature, and humidity. The temperature ranged between $19.26-19.29^{\circ} \mathrm{C}$, which is slightly above the ideal temperature for the growth of tea plants $\left(13-15^{\circ} \mathrm{C}\right)$, and relative humidity ranged from 87.54 to $89.04 \%$ during the day, which is higher than the optimal humidity of $70 \%$.

According to Loveless [35], a lack of water will cause protoplasm dehydration in leaves, which causes the stomata to eventually close and consequently inhibit the absorption of $\mathrm{CO}_{2}$. The dry weight of cultivated plants is the accumulation of net results of $\mathrm{CO}_{2}$ assimilation during growth, resulting 
from solar energy absorption and caused by sunlight. The main factors affecting plant dry weight are solar radiation absorption and the energy use efficiency of $\mathrm{CO}_{2}$ fixation.

Decreased plant growth can be caused by growth period decreases, low temperatures, limited groundwater, oxygen, limited root system nutrient supply, and limited root system activity. Groundwater plays a central role in these limiting factors, as it affects soil compaction for plant growth and biological functions related to water [36].

Plant growth periods are directly affected by climatic conditions such as changes in maximum and minimum daily temperatures and rainfall rates [37]. The reduction of water absorption decreases tissue water content which causes turgor loss. Likewise, drought stress also decreases assimilation and metabolites needed for cell division. This disrupts mitosis, cell extension, and ultimately plant growth [38].

During the plucking period, the weather is quite dry, which indirectly reduces the availability of groundwater. According to Marcelis et al. [37], a decrease in groundwater reduces the water absorption of plants and disrupts physiological and metabolic processes, altering plant morphology and physiology. In the dry season, the temperature in tea plantations is quite high. The temperature range strongly influences the growth of tea plants. Tea yield is susceptible to an increase in average monthly temperature, and a sustained increase further reduces tea yield [39].

\section{Catechin content}

The results of catechin analysis on picking production are displayed in Table IV (Fig.2 and Fig. 3), showing an interaction effect between pruning methods, pruning height, and PGR concentration on tea catechin levels. Catechin was initially known to accumulate during defense responses, fighting abiotic and biotic stress and also insects. Catechin found in tea plants act as anti-microbial (bacteria and viruses), antioxidants, anti-radiation, blood vessel strengtheners, urine secretion facilitators, and cancer cell inhibitors [40,41].

TABLE IV

INTERACTION EFFECT OF PRUNING METHOD, PRUNING HEIGHT AND PGR CONCENTRATION ON CATECHIN CONTENT

\begin{tabular}{|c|c|c|c|c|c|c|c|c|c|c|c|c|}
\hline \multirow{4}{*}{ Pruning type } & \multicolumn{12}{|c|}{ Plant Growth Regulator Concentration } \\
\hline & \multicolumn{3}{|c|}{0 ppm } & \multicolumn{3}{|c|}{60 ppm BAP } & \multicolumn{3}{|c|}{50 ppm GA } & \multicolumn{3}{|c|}{60 ppm BAP + 50 ppm GA } \\
\hline & \multicolumn{3}{|c|}{ Pruning height } & \multicolumn{3}{|c|}{ Pruning height } & \multicolumn{3}{|c|}{ Pruning height } & \multicolumn{3}{|c|}{ Pruning height } \\
\hline & $40 \mathrm{~cm}$ & $50 \mathrm{~cm}$ & $60 \mathrm{~cm}$ & $40 \mathrm{~cm}$ & $50 \mathrm{~cm}$ & $60 \mathrm{~cm}$ & $40 \mathrm{~cm}$ & $50 \mathrm{~cm}$ & $60 \mathrm{~cm}$ & $40 \mathrm{~cm}$ & $50 \mathrm{~cm}$ & $60 \mathrm{~cm}$ \\
\hline \multirow{2}{*}{ Clean pruning } & $1.21 \mathrm{~b}$ & $1.58 b$ & $1.07 \mathrm{a}$ & $1.24 \mathrm{a}$ & $2.14 \mathrm{~b}$ & $0.93 \mathrm{a}$ & $1.48 b$ & $1.61 \mathrm{~b}$ & $1.51 \mathrm{~b}$ & $1.34 \mathrm{a}$ & $1.59 \mathrm{a}$ & $0.83 \mathrm{a}$ \\
\hline & $\mathrm{B} / \underline{\mathrm{P}}$ & $\mathrm{C} / \underline{\mathrm{P}}$ & $\mathrm{A} / \underline{\mathrm{Q}}$ & $\mathrm{B} / \underline{\mathrm{PQ}}$ & $\mathrm{C} / \underline{\mathrm{Q}}$ & $\mathrm{A} / \underline{\mathrm{P}}$ & $\mathrm{A} / \underline{\mathrm{R}}$ & $\mathrm{A} / \underline{\mathrm{P}}$ & $\mathrm{A} / \underline{\mathrm{R}}$ & $\mathrm{B} / \underline{\mathrm{Q}}$ & $\mathrm{C} / \underline{\mathrm{P}}$ & $\mathrm{A} / \underline{\mathrm{P}}$ \\
\hline \multirow{2}{*}{ Lung pruning } & $0.92 \mathrm{a}$ & $0.80 \mathrm{a}$ & $1.39 \mathrm{~b}$ & $1.51 b$ & $1.05 \mathrm{a}$ & $1.40 \mathrm{~b}$ & $1.22 \mathrm{a}$ & $0.81 \mathrm{a}$ & $0.86 \mathrm{a}$ & $1.44 \mathrm{a}$ & $1.46 \mathrm{a}$ & $2.23 b$ \\
\hline & $\mathrm{A} / \underline{\mathrm{P}}$ & $\mathrm{A} / \underline{\mathrm{P}}$ & $\mathrm{B} / \underline{\mathrm{Q}}$ & $\mathrm{B} / \mathrm{R}$ & $\mathrm{A} / \underline{\mathrm{Q}}$ & $\mathrm{B} / \underline{\mathrm{Q}}$ & $\mathrm{B} / \underline{\mathrm{Q}}$ & $\mathrm{A} / \underline{\mathrm{P}}$ & $\mathrm{A} / \underline{\mathrm{P}}$ & $\mathrm{A} / \underline{\mathrm{R}}$ & $\mathrm{A} / \underline{\mathrm{R}}$ & $\mathrm{B} / \underline{\mathrm{R}}$ \\
\hline $\begin{aligned} \text { Note : } & \text { Figures fo } \\
& \text { read vertic } \\
& \text { concentrat } \\
& \text { which is a } \\
& \text { read horizc } \\
& \text { at each lev }\end{aligned}$ & $\begin{array}{l}\text { owed by } \\
\text { lly accord } \\
\text { of of PGR } \\
\text { ompariso } \\
\text { tally acc } \\
1 \text { (pruning }\end{array}$ & $\begin{array}{l}\text { same le } \\
\text { g to each } \\
\text { Uppercas } \\
\text { etween h } \\
\text { ling to ea } \\
\text { jpe : prun }\end{array}$ & $\begin{array}{l}\text { notation } \\
\text { lumn of } \mathrm{p} \\
\text { tters (A, } \\
\text { levels o } \\
\text { ow type } \\
\text { height) }\end{array}$ & $\begin{array}{l}\text { re not si } \\
\text { ining he } \\
\text { C) are } \\
\text { oruning } \\
\text { pruning }\end{array}$ & $\begin{array}{l}\text { ificantly } \\
\text { t which is } \\
\text { ad horizon } \\
\text { each stage } \\
\text { ross the P }\end{array}$ & $\begin{array}{l}\text { ferent bas } \\
\text { comparis } \\
\text { lly accord } \\
\text { f pruning } \\
\text { R concent }\end{array}$ & $\begin{array}{l}\text { on the I } \\
\text { between } \\
g \text { to each } \\
\text { pe and } P \\
\text { tion colu }\end{array}$ & $\begin{array}{l}\text { can test a } \\
\text { e stages o } \\
\text { w type of } \\
\text { concentr } \\
\text { is a comp }\end{array}$ & $\begin{array}{l}\text { o signific } \\
\text { uning typ } \\
\text { aning in e } \\
\text { n; underli } \\
\text { son betwe }\end{array}$ & $\begin{array}{l}\text { nce level; } \\
\text { at each hi } \\
\text { ch column } \\
\text { ed upperc } \\
\text { n the leve }\end{array}$ & $\begin{array}{l}\text { owercase } \\
\text { h level of } \\
\text { of PGR c } \\
\text { se letters } \\
\text { of PGR c }\end{array}$ & $\begin{array}{l}(\mathrm{a}, \mathrm{b}, \mathrm{c}) \text { are } \\
\text { runing and } \\
\text { ncentration } \\
, \underline{\mathrm{Q}}, \underline{\mathrm{R}}) \text { are } \\
\text { ncentration }\end{array}$ \\
\hline
\end{tabular}

The results showed that the treatment of clean pruning with $60 \mathrm{ppm}$ BAP at a pruning height of $60 \mathrm{~cm}$ provided the highest catechin content with a value of $2.14 \%$. In the pruned plot, the highest catechin content was obtained from the treatment of $60 \mathrm{~cm}$ pruning height and PGR concentrations of $60 \mathrm{ppm}$ BAP +50 ppm GA with a value of $2.23 \%$. Several research results show that the biosynthesis of secondary metabolites depends on various environmental cues (light, temperature, $\mathrm{CO} 2$, dryness, salinity, ozone, UV radiation) and endogenous signals (hormones and signaling molecules). Even if other factors remain constant, changes to only one factor can substantially change the concentration of endogenous secondary metabolites [42].

When depicted in the response surface graph, the catechin content of plants that underwent clean pruning shows a regression equation: $\mathrm{Z}=(-6.7122)+(0.328) x+(0.00398) y+$ $(-0.00329) x^{2}+(-0.00009) y^{2}+(0.00015) x y$ where $Z=$ catechin levels $(\%) ; x=$ pruning height $(\mathrm{cm}) ; y=$ PGR concentration (ppm).

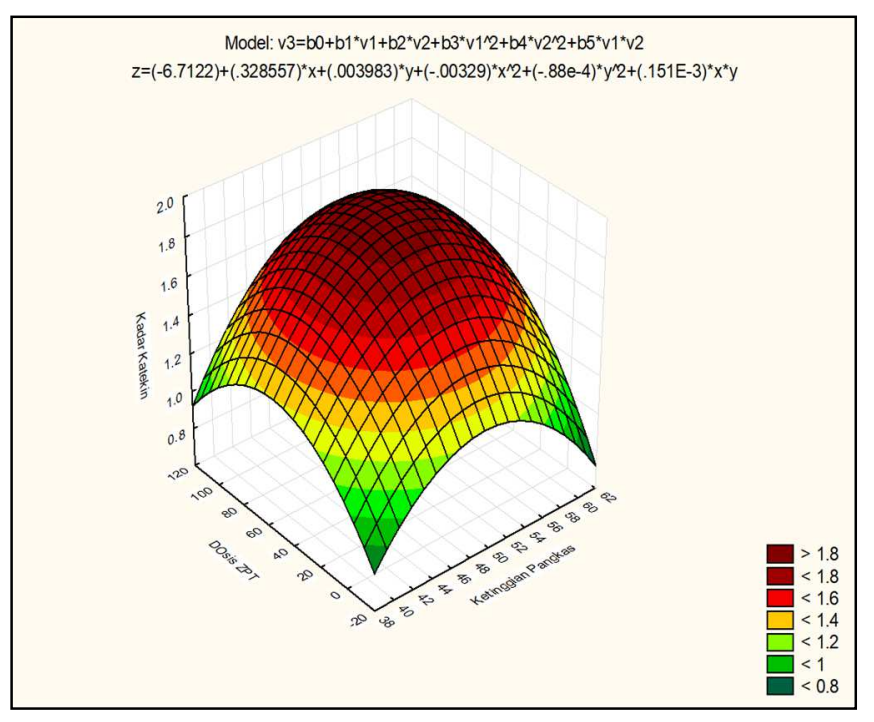

Fig. 2 The graphic surface response of pruning height and concentration of growth regulators on clean pruning to tea catechin content 
Model: $\mathrm{v} 3=\mathrm{b} 0+\mathrm{b} 1^{*} \mathrm{v} 1+\mathrm{b} 2^{*} \mathrm{v} 2+\mathrm{b} 3^{*} \mathrm{v} 112+\mathrm{b} 4^{*} \mathrm{v} 2^{12}+\mathrm{b} 5^{*} \mathrm{v} 1^{*} \mathrm{v} 2$ $z=(10.1161)+(-.37172)^{*} x+(-.00912)^{*} y+(.0037)^{*} x^{N} 2+(.661 e-4)^{*} y^{\prime 2}+(.163 E-3)^{*} x^{*} y$

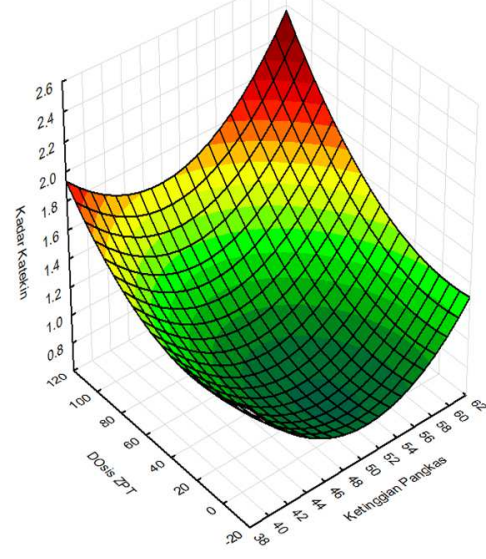

roots. De Costa et al. states that photosynthates produced in immature leaves do not move. However, older leaves do not parasitize other leaves when they become unproductive [47].

The percentage of catechins in the GMB 7 clone shows that the results of Sriyadi's research is $p+2$ dry, which is around $0.0001 \%$ [48]. GMB 7 is a superior variety of tea with high productivity, possess antioxidant potential, and can grow well in low, medium, and high altitudes [49]. Although processing technologies have an impact on the quality of tea, according to Zhang et al. [50], geographical location and other environmental factors also have significant effects. The constituents of polyphenolic compounds, especially individual catechins, depend on cultivation altitude; higher altitude equals a higher catechin count.

Furthermore, according to Han et al., temperatures have seen an increase due to climate change which means that temperatures are also increasing at low altitudes and will decrease tea quality. Other negative impacts of global warming on the production and quality of tea, especially regarding rising temperatures include unpredictable rainfall trends and increased frequency of extreme weather events such as drought and frost [51]. In most plants, physiological and biochemical responses to combat the effects of environmental stress include lowering cellular growth and net photosynthesis rates, stomatal closure, and the accumulation of organic solutes [52].

\section{CONCLUSION}

Interaction between $60 \mathrm{~cm}$ pruning height and $60 \mathrm{ppm}$ BAP increase chlorophyll content index $(91.581 \mathrm{cci})$ in 3rd month, meanwhile interaction of $50 \mathrm{ppm}$ GA at the same level pruning height influence shoot fresh weight per bush at on the 4th plucking. Based on the response curve analysis, clean pruning type with optimum pruning height at $51.5 \mathrm{~cm}$ and 66.63 ppm BAP contribute to highest catechin content $(1.88 \%)$. This research concludes that the application of 60 ppm BAP on $60 \mathrm{~cm}$ clean pruning height at the $3^{\text {rd }}$ month and follow with $50 \mathrm{ppm} \mathrm{GA}$ at the $4^{\text {th }}$ plucking, recommended to increase vegetative growth and catechin content of tea shoot after pruning.

\section{ACKNOWLEDGMENT}

The authors are grateful to the BBPDN Scholarship Kemenristek DIKTI 2017 and Gambung Research Institute for Tea and Cinchona for willingness and support to provide a place for experiment.

\section{REFERENCES}

[1] Direktorat Jendral Tanaman Perkebunan. Pengaruh Iklim dan Kejadian La Nina dan Antisipasinya Terhadap Produksi Tanaman Teh Kementrian Pertanian. 2018.

[2] (20I8). Indonesia Investment. Tea website.[Online]. Available https://www.indonesiainvestments.com/id/bisnis/komoditas/teh/item 240

[3] Y. Jiang, J. Hua, B. Wang, H.Yuan, and H. Ma, "Effects of Variety, Season, and Region on Theaflavins Content of Fermented Chinese Congou Black Tea, Journal of Food Quality. vol.1, pp. 1-9, Nov. 2018.

[4] W.Y. Han, J. Huang, X. Li, Z. Li, G.J. Ahammed, P. Yan, and J.R. Stepp, " Altitudinal effects on the quality of green tea in east China: a climate change perspective,", Eur Food Res Technol.vol. 243, pp. 323330, July. 2016.

[5] C. Zhang, C.L.C. Suen, C. Yang and S.Y. Quek, "Antioxidant capacity and major polyphenol composition of teas as affected by 
geographical location, plantation elevation and leaf grade," Food Chem., vol. 244, pp. 109-119. 2018

[6] S.L. Dalimoenthe, "Tea (Camellia sinensis) Sustainable Technology," in the Proceedings of the Sustainable Tea Industry Technical Meeting, 2006, p. 49-68

[7] M. Wakamatsu, H. Yamanouchi, H. Sahara, T. Iwanaga, R. Kuroda, A. Yamamoto, Y. Minami, M. Sekijima, K. Yamada, and K. Kajiya,

" Catechin and caffeine contents in green tea at different harvest periods and their metabolism in miniature swine," 2019, Food. Sci. Nutr. vol. 7, pp 2769-2778, Aug. 2019.

[8] S. Firouzi and F. Azarian, "Propellants of mechanical pruning and plucking of tea (a case of developing countries)," 2019, Information Processing in Agriculture. vol. 6, pp. 454-461.

[9] Q. Zhang, T. Li , Q. Wang, J. LeCompte, R. L. Harkess and G. Bi, "Screening Tea Cultivars for Novel Climates: Plant Growth and Leaf Quality of Camellia sinensis Cultivars Grown in Mississippi, United States.," Front. Plant Sci., vol.11, pp. 1-12, March. 2020.

[10] K.C. Mohale, A.T. Hintsa, M.A. Emanuel and F.N. Mudau, "Metabolic Profiling of Cultivated Bush Tea. (Athrixiaphylicoides DC.) in Response to Different Pruning Types," Hortscience, vol. 53, pp. 993-998. July. 2018.

[11] Leduc N, Roman H, Barbier F, Péron T, Huché-Thélier L, Lothier J Demotes-Mainard S, S. S. (2014). Light signaling in bud outgrowth and branching in plants. Plants (Basel), 3(2), 223-250. https://doi.org/10.3390/plants3020223

[12] Z.H. Lee, T. Hirakawa, N. Yamaguchi and T. Ito, "The Roles of Plant Hormones and Their Interactions with Regulatory Genes in Determining Meristem Activity (review),” J. Mol. Sci., vol. 20, pp. 1-19.Aug. 2019

[13] L. Zhang , C. Shen , J. Wei and W. Han, "Effects of Exogenous 6Benzyladenine on Dwarfing, Shoot Branching, and Yield of Tea Plant (Camellia sinensis)," Hort. Science., vol. 53, pp. 651-655. Aug.2018.

[14] I.R.D Anjarsari, J.S Hamdani, C. Suherman and T.Nurmala, "Effect of Pruning and Cytokinin Application on the Growth of Tea GMB 7 Clone," Asian J. Plant Sci., vol. 18, pp. 110-116. June. 2019.

[15] S. Rosniawaty, I.R.D Anjarsari \& R. Sudirja,"Application Of Cytokinins To Enhance Tea Plant Growth In The Lowlands," Journal of Industrial and Beverage Crop,vol. 5, pp. 31-38. 2018

[16] Shu, K, W. Zhou, F. Chen, X. Luo and W. Yang," Abscisic Acid and Gibberellins Antagonistically Mediate Plant Develelopment and Abiotic Stress Responses," Front. Plant Sci., vol.9 pp. 1-8. March.2018.

[17] H. Li, T. Garcia, J., D. Latrasse, M. Benhamed, S. Schilderink, W. Zhou,"Plant-specific histone deacetylases HDT $1 / 2$ regulate gibberellin 2-oxidase2 expression to control Arabidopsis root meristem cell number,"Plant Cell., vol. 29, pp. 2183-2196. Sept. 2017.

[18] B. Wang, H. Wei, Z. Xue, and W.H. Zhang, "Gibberellins regulate iron deficiency-response by influencing iron transport and translocation in rice seedlings (Oryza sativa)," Ann. Bot. 119, vol.pp. 945-956. 2017

[19] Official Method of Analysis of the Association of Official Analytical Chemists (AOAC). The Association of Official Analitical Chemists Inc. 1984.

[20] M.I.P. Atmaja, Shabri, H.S. Khomaini, H. Maulana, S. Harianto and D. Rohdiana, "Changes in chlorophyll and polyphenols content in Camellia sinensis var. sinensis at different stage of leaf maturity," in IOP Conf. Series: Earth and Environmental Science, 2018, p.1-7.

[21] P.J. Davies, The Plant Hormones: Their Nature, Occurrence, and Functions, Department of Plant Biology. Cornell University, Ithaca, New York 14853, USA, 2008

[22] B. Wang, H. Wei, Z. Xue, and W.H. Zhang, "Gibberellins regulate iron deficiency-response by influencing iron transport and translocation in rice seedlings (Oryza sativa)," Ann. Bot. 119, vol.pp. 945-956. 2017

[23] X. Zhuang, L. Jiang, "Chloroplast Degradation: Multiple Routes Into the Vacuole (mini Review Article)," Front. Plant Sci., vol.10 , pp. 18 , March. 2019.

[24] L. Juez, K.A. Epyke, "Plastids unleashed: their development and their integration in plant development," International Journal of Developmental Biology, vol. 49, pp. 557-577, Nov. 2005.

[25] D. Procházková, D. Haisel and N. Wilhelmova, "Antioxidant protection during ageing and senescence in chloroplasts of tobacco with modulated life span," Cell Biochemistry and Function, vol. 26, pp. 582- 590. May. 2008.

[26] Z.X. Li, W.J. Yang, G.J. Ahammed, C. Shen, P. Yan, X. Li and W.Y. Han, "Developmental changes in carbon and nitrogen metabolism affect tea quality in different leaf position," Plant Physiol. Biochem, vol. 106 , pp. 327-335, Sept. 2016

[27] J. Binenbaum, R. Weinstain, and S. Shani, "Gibberellin Localization and Transport in Plants," Tend In Plant Science, vol.23,pp. 410-421, May. 2018.

[28] C. Yue, H. Cao, X. Hao, J. Zeng, W. Qian, Y. Guo, N. Ye, Y. Yang , X. Wang, "Differential Expression of Gibberellin- And Abscisic Acid-Related Genes Implies Their Roles in the Bud ActivityDormancy Transition of Tea Plants," Plant Cell Rep., vol. 37, pp. 425441.March. 2018.

[29] K. Shu, W. Zhou, F. Chen, X. Luo and W. Yang, “Abscisic Acid and Gibberellins Antagonistically Mediate Plant Develelopment and Abiotic Stress Responses," Front. Plant Sci., vol. 9, pp. 1-8. March. 2018

[30] H. Li, J.T. Garcia, D. Latrasse, M. Benhamed, S. Schilderink, W. Zhou, "Plant-specific histone deacetylases HDT1/2 regulate Gibberellin 2-Oxidase2 expression to control Arabidopsis root meristem cell number," Plant Cell , vol. 29, pp. 2183-2196. Sept. 2017

[31] Y. Wen, S. Su, L.Ma \& X. Wang, "Effects of gibberellic acid on photosynthesis and endogenous hormones of Camellia oleifera Abel in 1st and 6th leaves," Journal of Forest Research, vol. 23, pp. 309317. Sept. 2018.

[32] N.G. Halford, Photosynthate partitioning.Plant Developmental Biology - Biotechnological Perspectives, eds Pua E. C., Davey M. R., editors. Berlin; Heidelberg: Springer, 2010

[33] N. Subarna, "Economic analysis of the effect of fine, medium, and coarse plucking on the average of tea pluckers and plant productivity," in 5st Tea Prosiding Simposium Bandung, 1990, p. 469-479.

[34] S. Mitrowihardjo, "Catechin content and shoot yield of several superior tea clones (Camellia sinensis (L.) O. Kuntze) at different altitudes in Pagilaran plantation," Dissertation, Program Studi Pemuliaan Tanaman. Fakultas Pertanian UGM, Yogyakarta. 2012.

[35] A.R. Loveless, Principles of Plant Biology for Tropical Areas I, Gramedia Pustaka Utama: Jakarta.1991.

[36] F.P. Gardner, R. B. Pearce, and R. L. Mitchell, Fisiologi Physiology of Crop Plants. Iowa State University Press. 1991.

[37] Y.O. Koca, O. Erekul, "Changes of Dry Matter, Biomass and Relative Growth Rate with Different Phenological Stages of Corn, Agriculture and Agricultural Science Procedia, vol.10, pp. 67-75. 2016.

[38] M. Farooq, A. Wahid, N. Kobayashi, D. Fujita, and S.M.A. Basra, "Plant drought stress: effects, mechanisms and management. A gronomy for Sustainable Development,"vol. 29, pp.185-212. March. 2009.

[39] R. Hajiboland, "Environmental and nutritional requirements for tea cultivation, Folia Hort., vol. 29, pp. 199-220. 2017.

[40] A.L. Tariq and A.L. Reyaz, "Phytochemical analysis of Camellia sinensis leaves," Int. J. of Drug Development and Research, vol. 4, pp. 311-316. 2012.

[41] O.B. Aigbodion, I. Marcell, "Microbiological characteristics and phytochemical screening of some herbal teas in Nigeria," European Scientific Journal, vol.9, pp. 149-160. June.2013.

[42] N. Verma, S. Shukla, "Impact of various factors responsible for fluctuation in plant secondary metabolites, J. App. Res. Med. Arom. Plants, vol. 2, pp. 105-113. Dec.2015.

[43] Giannakoula, "The effects of plant growth regulators on growth, yield, and phenolic profile of lentil plants," Journal of Food Composition and Analysis, vol.28, pp. 46-53. Nov. 2015.

[44] M.N. Fhatuwani, M.P. Nokwanda, 'Effect of Seasonal Variations and Growth Conditions on Carbohydrate Partitioning in Different Organs and the Quality of Bush Tea," HortScience, vol. 53, pp. 999-1005. July. 2018.

[45] Y. Jiang, J. Hua, B. Wang, H. Yuan, and H. Ma, "Effects of Variety, Season, and Region on Theaflavins Content of Fermented Chinese Congou Black Tea," Journal of Food Quality, vol.2018 pp. 1-9. Nov. 2018

[46] T. Samanta, J.N.R. Kotamreddy, B.C. Ghosh and A. Mitra, “ Changes in targeted metabolites, enzyme activities and transcripts at different developmental stages of tea leaves: a study for understanding the biochemical basis of tea shoot plucking," Acta Physiol. Plant. vol. 39, pp. 1-11. 2017.

[47] D.Costa, W.A.J.M, A.J.A Mohotti and M.A. Wijeratne,' Ecophysiology of tea (Review),” Braz. J. Plant Physiol., vol. 19, pp. 299-332, Oct. 2007

[48] B. Sriyadi, "Seleksi klon teh assamica unggul berpotensi hasil dan kadar katekin tinggi," Jurnal Penelitian Teh dan Kina vol.15, pp. 110. 2012 
[49] B. Martono, S. Falah, and E. Nurlaela," Antioxidant Activities Of Gmb 7 Variety OfTea At Different Altitude," Journal of Industrial and Beverage Crops, vol. 3, pp. 53-60. March. 2017.

[50] C. Zhang, C.L.C. Suen, C. Yang, S.Y. Quek, "Antioxidant capacity and major polyphenol composition of teas as affected by geographical location, plantation elevation and leaf grade," Food Chem vol. 244, pp. 109-119. Apr. 2018.
[51] S. Ahmed, T. Griffin, S.B. Cash, W.Y. Han, C. Matyas, C and C, Long, Global climate change, ecological stress, and tea production in Stress Physiology of Tea in the Face of Climate Change, Singapore: Springer, 2018.

[52] C.R. Muoki, T.K. Maritim, W.A. Oluoch, S.M. Kaumya and J. K. Bore, "Combating Climate Change in the Kenyan Tea Industry. 2018. (Review Article),” Front. Plant Sci., vol. 11, pp.1-10. 